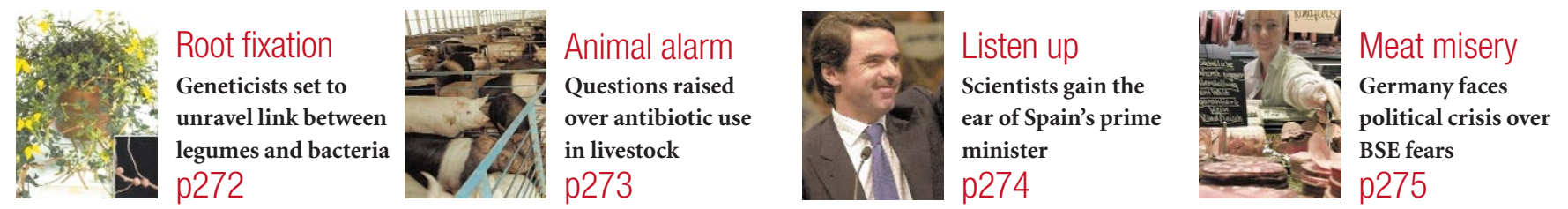

\title{
Harvard to spend 'hundreds of millions' on further expansion
}

\section{Rex Dalton}

Harvard University is planning to invest hundreds of millions of dollars in a new natural history museum, an expanded faculty and extra facilities for scientific research and teaching.

The cost has not been determined, but some estimates put the total at over $\$ 700$ million. Jeremy Knowles, dean of the faculty of arts and sciences, says the cost "would be in the hundreds of millions of dollars over the next five years". The move follows a $\$ 200$ million investment in new science institutes announced just two years ago.

Investment profits from Harvard's $\$ 19.2$ billion endowment - which earned a 32\% return for the year ending last June - will be used to finance the undertaking, officials say.

Rather than "just running on a richer mixture", says Knowles, Harvard plans to "grasp the opportunity to improve the quality of the undergraduate experience and the lives of graduate students and faculty".

During the next decade, six new chairs will be added to the faculty each year. The 60 new positions will be spread across all disciplines in the Faculty of Arts and Sciences, which currently has 650 professors, 3,500 graduate students and 6,500 undergraduates.

Several extra buildings for teaching and research will be built in the North Yard section of Harvard's campus at Cambridge, Massachusetts, next to the existing Museum of Comparative Zoology.

The new natural history museum, whose name and site have yet to be chosen, will put collections from several of Harvard's existing museums on public display, and the university's various scholarly collections will be updated and improved, Harvard officials say. The university's popular Glass Flowers collection of more than 4,000 botanical models will be a central feature in the new museum. Collections will also be housed there from the zoology museum, the Peabody Museum of Archaeology and Ethnology, the Mineralogical and Geological Museum, and the Botanical Museum.

The new museum and the updating of Harvard's scholarly collections are seen as an important contribution to the overall health

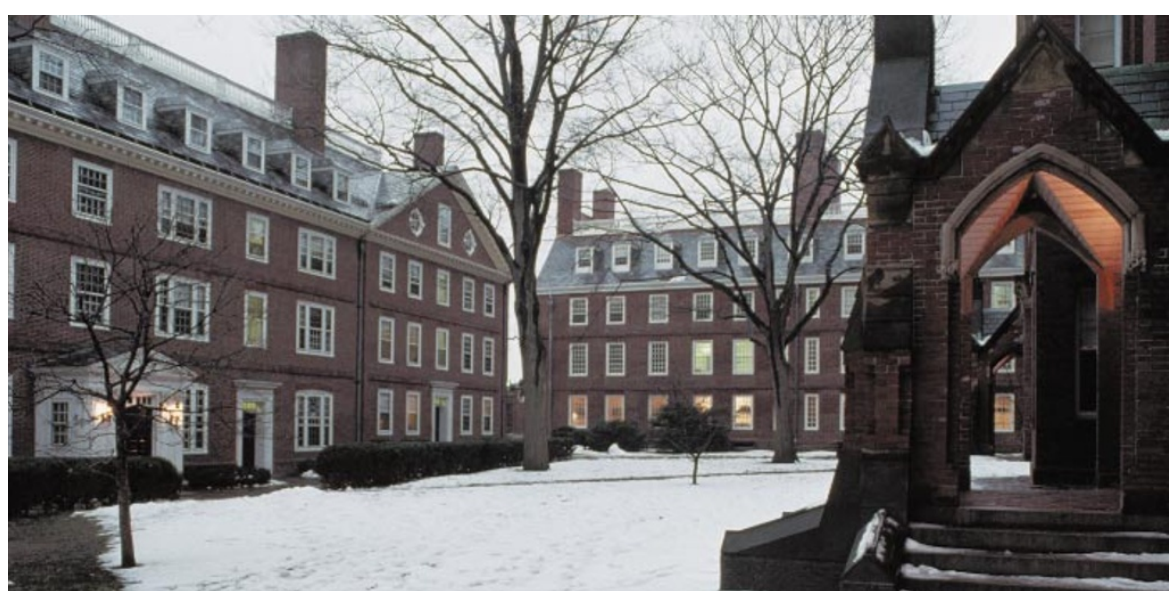

Solid backing: Harvard will fund growth using profits from its $\$ 19.2$ billion endowment fund.

of single-organism biology in the United States. "This all underscores the exciting time, showing the renewed potency of natural history museums and their collections," says James Hanken of Harvard's department of organismic and evolutionary biology.

The new buildings and areas vacated by museum collections, will house new laboratories, teaching areas and offices.
The plan comes two years after Harvard announced a major investment in facilities to house new institutes in genomics, nanotechnology, computer science and climate research. The Bauer Center for Genomic Research is under construction, and plans are being drawn up for the Center for Imaging and Mesoscale Structures.

http://www.harvard.edu

\section{Biotech sector still looking lively}

Sally Lehrman, San Francisco

The Nasdaq high-technology stock market has just finished its worst year ever, and biotechnology stocks have been hit particularly hard over the past few weeks. But raising money for biotechnology ideas has never been easier, visitors to the sector's annual financial jamboree were told.

According to Wall Street analysts at the J. P. Morgan H\&Q Healthcare conference in San Francisco last week, opportunities to develop new ideas in biotech are as strong as ever. Venture funding is robust, and commercial companies with cash available are also looking to invest.

Even though biotechnology stocks fell towards the end of 2000, many companies had used the positive market of the previous 12 months to strengthen their financial position. Biotechnology concerns raised an estimated $\$ 35$ billion in total during 2000 , making it a record year.

In the third quarter of 2000, venture capitalists put $\$ 708$ million into biotechnology companies, according to Pricewaterhouse Coopers: $150 \%$ more than in the same period of 1999.

The meeting also heard that a new subsector is emerging: 'post-genomics' companies, developing analytical techniques and high-speed technology to accelerate the translation of genomics into drug therapies. Robert Olan, a biotechnology analyst for J. P. Morgan H\&Q in New York, said that universities have become more sophisticated about licensing agreements, and competition for their inventions has increased. 